ARTICLE

\title{
The Implication of Law No. 11 Of 2020 Concerning Job Creation Towards Regulation on The Permit to Open Land State in East Kalimantan
}

\section{Mohamad Nasir}

Cultural Anthropology and Development Studies, Radboud University, The Netherlands; Faculty of Law, Universitas Balikpapan, Jl. Pupuk Raya, Kel. Damai Bahagia, Balikpapan, Indonesia

How to cite: Nasir, Mohamad. (2021). The Implication of Law No. 11 of 2020 concerning Towards Regulation on the Permit to Open Land State in East Kalimantan. Jurnal Borneo Administrator, 17(2), 155-168. https:doi.org/10.24258/jba.v17i2.842

\section{Article History \\ Received: 10 February 2021}

Accepted: 18 Mei 2021

\section{Keywords:}

Land State Permit, Regulation Disharmony, East Kalimantan

\begin{abstract}
Four regions in East Kalimantan province, including Balikpapan, Kutai Kartanegara, Penajam Paser Utara, and Samarinda, have local regulations known as Perda concerning the permission to open land state (IMTN). As a licensing instrument, IMTN has closely related to other sectors, such as investment, public services, and regional government. The policy's dynamics and changes in those sectors will impact the land sector, including the IMTN regulation. This article aims to examine two issues. First, the status of IMTN norms in licensing law regimes. Second, the conformity of the Perda along with the development of the higher regulations. In particular, the implication of Law No. 11/2020 to Perda IMTN in East Kalimantan and formulate alternative solutions to address the dynamics of land policy at the national level. This research applies normative legal analysis (doctrinal) to examine the relationship between norms within related regulations. This paper reveals that IMTN norms in licensing law regimes are unclear. De jure is a permit, and it means that IMTN should be given before the activities to open state land are conducted (constitutive). De facto, IMTN has more value as an instrument to reaffirms the existing land (declarative). Thus, for its relation to higher regulations, the Perda has not accommodated some provisions on administrative efforts as stipulated in Law No. 30/2014, complaint management as mandated by Law No. 25/2010, and the risk-based approach in business licensing as introduced by Law No. 11/2020. Therefore, Perda on IMTN should be amended or replaced to adjust to higher regulations' norms.
\end{abstract}

\section{A. INTRODUCTION}

The land has a significant role in the life of most Indonesian people. The land is not merely perceived as a physical object but also a resource in which social, cultural, economic, and political space is built (Supriyanto, 2008:221). The various dimensions in the relationship between land and humans make the ownership of land changes, and control arrangements affect the pattern of relations between humans themselves. Inequality in land patterns of ownership has impacts on social, economic, and even political relations (Bachriadi \& Wiradi, 2011:6-11; Sauni, 2017:62-66; Shohibuddin, 2019:143-144).

\footnotetext{
* Corresponding Author

Email: mohamad.nasir@uniba-bpn.ac.id
} 
The strategic value of land is confirmed in the concept of the right control of natural resources as mandated in article 33 paragraph (3) of the 1945 Indonesian Constitution. Further, Law No. 5 of 1960 concerning Basic Regulation on Agrarian Principles (Law No. 5/1960) outlines such rights provides government authority as follows: (a) to regulate and implement the appropriation, the utilization, the reservation, and the cultivation of land; (b) to determine and regulate the legal relations between persons with the land; and (c) to determine and regulate the legal relations between persons and legal acts concerning the land.

According to Sumardjono (2018:38), referring to Law No. 5/1960, in the relationship between the state and land, there are three land entities, namely: (a) state land whose authority has a public aspect; (b) private land owned by individuals or legal entities with a civil aspect authority; and (c) customary land of the indigenous peoples with public and civil perspective authority.

Furthermore, Law No. 5/1960 mentions that the manifestation of the state's right of control may be delegated to the autonomous region as long as it is not in conflict with the national interest and laws and regulations. In the context of regional autonomy, under Law Number 23 of 2014 concerning Regional Government (Law No. 23/2014), the district/city governments' authority regarding the land is a part of concurrent government affairs, that is, mandatory government affairs related to essential services.

In East Kalimantan, as stated in the Regional Medium-Term Development Plan (RPJMD) 2019 - 2023, land affairs are essential issues in regional development, primarily related to assets, legality, and land conflicts. The planning document conveys that this province experiences an increasing spatial conflict. There are 4.86 million hectares of overlapping permits between forestry, plantations, and mining. The chaotic spatial use of the East Kalimantan has caused instability in social and economic conditions. Forestry, plantations, and mining have controlled about 88.47 percent of land in the province. Also, settlements in rural areas in forest areas, large plantations, and mining concessions cannot be maximized in managing land, and access to primary infrastructure services is still limited. East Kalimantan's poor people mainly occur in these overlapping areas. According to the planning document, control of spatial use needs to be directed at restructuring natural resource management patterns by controlling investment licensing, such as increasing the legal certainty of land rights.

One of the instruments to ensure land rights' legal certainty is the permit to open state land (Izin Membuka Tanah Negara: IMTN). The authority of district/city governments in issuing this permit is regulated in Law No. 23/2014, particularly in Appendix J concerning Government Affairs in the land sector. In East Kalimantan province, four regions have local regulations (Perda) regarding IMTN. Balikpapan has set such Perda in 2014 and was followed by Kutai Kartanegara district and Penajam Paser Utara district (2017), and Samarinda (2019). The four Perda have similar substances and systematics with some improvisations in several articles to adjust to each region's conditions.

As a licensing instrument, IMTN has closely related to other sectors, such as investment, public services, and local government (authority). The dynamics of development and policy change in these sectors also affect the land sector. Therefore, land policy, including the IMTN, must be regularly evaluated to ensure that existing regulations remain in line with the developments.

An examination of the Perda regarding IMTN in East Kalimantan needs to be carried out considering that in November 2020, the central government enacted Law Number 11 of 2020 concerning Job Creation (Law No. 11/2020). In this law, there are at least three provisions relating to regional authority in issuing IMTN, that are: (a) Law No. 11/2020 changed the approach in controlling an activity from a licensing approach to a risk-based approach. Under this law, the term "license" is only applied to high-risk business activities. It 
then raises a question to IMTN, is the activity included in IMTN (to open, use, and utilize state land) could be categorized as high-risk business activities; (b) In Article 181 of Law No. $11 / 2020$, it is explained that as the law promulgated, every regulation under Law No. 11/2020 has contradicted provisions with the law that should be harmonized and synchronized. A review of regional legal products related to the IMTN in East Kalimantan is relevant in this context; and (c) The provisions of Law No. 11/2020 order that the division of concurrent government affairs between the central and provincial governments and district/city as stated by Law No. 23/2014 must be read and interpreted following the provisions stipulated in Law No. 11/2020. Thus, the stipulations regarding the IMTN also must be read as part of the business licensing framework.

Besides, IMTN is also related to government employees/civil servants' services, and it is also necessary to review whether the provisions in the four Perda are following Law No. 30 of 2014 concerning Government Administration (Law No. 30/2014) and Law No. 25 of 2009 concerning Public Servants ( Law No. 25/2009) or not.

The promulgation of Law No. 11/2020 raises a crucial question about the content of Perda regarding IMTN. How is the position or status of IMTN norms in licensing law regimes? Whether the norms within the Perda are following and consistent with higher regulations, especially Law No. 11/2020? What efforts should be taken to adjust to the inconsistent provisions?

In response to the problems, this article examines the regulations on IMTN in East Kalimantan. The analysis of the content (substance) of the regulation intends to investigate how the IMTN's position in the legal framework of licensing, theoretically and based on statutory regulations. This review also aims to ensure whether the provisions contained in several regional regulations regarding IMTN in East Kalimantan are still following the development of the existing laws and regulations or not. In particular, this article will analyze the implication of Law No. 11/2020 to regulations governing IMTN in East Kalimantan and formulate alternative solutions in addressing the dynamics of land policy at the national level.

\section{B. LITERATURE REVIEW}

Current studies of IMTN focus predominantly on three main issues, that are the status of the sale, the purchase of land based on IMTN (Rukmana \& Darmini, 2015; Sari, 2017), the legal status of IMTN in land registration (Dear, 2017; Luhfitasari et al., 2020; Permatasari et al., 2015), and the implementation of Perda on IMTN (Budiman, 2020; Jade et al., 2020; Tim Kajian Kebijakan Publik ORI Kalimantan Timur, 2019). In terms of location, all of these studies highlighted on Perda of IMTN in Balikpapan. There is no research analyze Perda on IMTN in other regions in East Kalimantan.

Concerning the impact of Law No. 11/2020 on the land sector, we can trace it in an analysis carried out by the Faculty of Law, Gajah Mada University. However, this study focuses more on land acquisition, land, bank, and conversion of agricultural land functions (Riyanto et al., 2020); it did not discuss the IMTN. The Indonesian Center for Environmental Law (ICEL) also conducted a similar study, but it focused more on land in plantations and spatial planning (Anindarini et al., 2020). There are no studies found examining the implications of Law No. 11/2020 to the regional authorities in managing the state land.

This topic is significant because a comprehensive understanding of this law's implications is required, and considering the law, which changes the business licensing paradigm from a licensing approach to a risk-based approach. In the context of IMTN, this paradigm shift does not only have implications for regional legal products related to IMTN (regional regulations or regional head regulations) but also permit term (in IMTN) and licensing institutions related to IMTN such as districts, integrated investment and licensing 
service (Dinas Penanaman Modal dan Perizinan Terpadu/DPMPT), land and spatial planning service (Dinas Pertanahan dan Penataan Ruang/DPPR). Through a better understanding of its implication, local governments can reformulate their IMTN regulations and improve the IMTN's institution and harmonize it with the higher policies and regulations.

In analyzing the statutory regulations, this study departs from the legal hierarchy theory proposed by Hans Kelsen. According to this theory, legal norms are terraced and constitute multi-layered arrangements in a hierarchy. It is derived and based on the norm above it, and it also becomes the source of legal norms that lie underneath, which will then reach the highest, known as the basic norm (Asshiddiqie \& Safaat, 2006:94; McLeod, 1999:69).

This paper adopted a vertical analysis to examine the relationship between laws, government regulations, and district regulations. This analysis intends to investigate the consistency of the content between the laws and the regulations underneath. In this stage, we analyzed the conflict of norms by using the lex superior principle (lex superior derogat legi inferior), which means that the provision with a higher level overrules a provision with a lower one. To shape the analysis, the author used legal harmonization theory, which refers to a convergence of national legal systems, reducing and eliminating differences (Bezborodov, 2017:24-26).

In a broader sense, harmonization is not only related to the relationship between higher and lower laws and regulations, but also with the relationship between sectoral laws and regulations, between statutory regulations and administrative regulations, statutory regulations and court decisions, formal rules, and social rules, and between national and international law (Goesniadhie, 2006:114-115; Otto et al., 2008:70-71; Soegiyono, 2015:8). L.M. Gandhi points out several causes of disharmony, among others, the difference between 1) statute and customary law, 2) laws and court decisions, 3) higher and lower laws and regulations, 4) central regulations and regional regulations, and 5) conflicts of authority between government agencies (Shidarta, 2005:10). In law, the term contradiction of norms (contra legem) and mismatching norms (praepria) is distinguished (Asshiddiqie, 2000:10; Ichsan et al., 2020:26). Regulation is not allowed to regulate norms that contradict with norms regulated in a higher regulation. However, if the regulated content is not contradictory but does not comply (not match) with provisions in a higher regulation, it is still legally acceptable.

The author used two concepts to investigate the content of regulations: the law's ambiguity and the law's incompleteness. The word ambiguity means uncertainty of meaning or intention, as in a contractual term or statutory provision (Garner, 2009:93) or uncertainty or doubtfulness of language's meaning (Batten, 2010:257). As for the incompleteness, Pistor and $\mathrm{Xu}$ (2003:932) articulate that a law may be incomplete to specify comprehensively actions that shall be covered which may result in a similar harmful outcome. The term 'incomplete' also refers to when implementation regulations or guidelines mandated by higher regulation do not exist (Waddell, 2004:186).

Further, to analyze the status of the IMTN as a permit, this paper departs from the analysis of government actions in the context of administrative law. There are four types of government legal actions in administrative law: decision, plans, regulating, and pseudolegislation (Herman, 2015:48; Suyani, 2016:15). Concerning the decision (beschikking), it has beneficial legal consequences. On the other hand, it is considered detrimental to society. The basis for granting permits to individuals or private legal entities is the emergence of strategies and techniques used by the government to control various situations performing certain activities without written permission from the government. In other words, through this licensing system, the authorities intervene in the process of community activities (Lofus, 2019:8). 
From the perspective of administrative law, a permit is a preventive instrument that has functions, such as 1) to direct/control activities, 2) to prevent harm to the environment, 3) to protect specific objects, 4) to regulate the distribution of rare objects, and 5) to select the specific people or activities (Asyiah, 2017:124; Sutedi, 2011:11-17). As a preventive instrument, every official is authorized to issue a permit with consideration to the legal certainty principle (rechtmatigheid) and the benefit principle (doelmatigheid) (Sugiharto \& Abrianto, 2018:57).

The legal certainty principle covers issues of authority, procedure, and substance that describe the understanding of state administration officials on administrative law norms, which are the guidelines for carrying out government actions (permits), and this will be assessed based on measuring instruments in the form of statutory regulations and administrative law norms. Meanwhile, the efficiency principle is related to the goals intended and achieved by the administrative law provisions carried out by officials who issue permits. As a decision of an official/state administrative body, a permit must be in line with two things: laws and regulations and general principles of good governance (Asas-asas Umum Pemerintahan yang Baik/AAUPB). Meanwhile, the definition of AAUPB is the principle of legal certainty, the principle of orderly state administration, the principle of public interest, the principle of transparency, the principle of professionalism, and the principle of accountability (Hadi \& Michael, 2017:397).

\section{METHOD}

This study adopts normative legal research (doctrinal). This approach will examine the relationship between norms within laws and regulations related to the object of study. The doctrinal approach is applied to identify the ambiguity, incompleteness and disharmony of norms that regulate the IMTN. Doctrinal analysis of law is primarily concerned with the extent to which authoritative legal texts (laws, regulations, and court decisions) (Hutchinson, 2016:131; Kharel, 2018:4) are consistent and coherent so that they can bring about certainty and equality (Hesselink, 2009:22).

Specifically, this research is an investigation of horizontal and vertical synchronization of laws and regulations. The data used in this study are secondary, consisting of laws and regulations, literature, and other official documents related to land issues. The data collection was conducted by taking an inventory and identifying relevant legal materials through a desk review. To analyze the relevant laws and regulations, the authors begin with the grammatical interpretation (what does it linguistically mean). This interpretation departs from the meaning according to everyday language usage or the technical-juridical meaning, which is expected or considered standard. After finding the meaning of the terms according to language and law, the next step is to carry out a systematic interpretation (the articles' theme or how to understand the articles according to the formulation's grouping systematically) (Afif Khalid, 2014:12-15). Using this method of interpretation, the author examines the relationship between articles in one regulation or between regulations, both horizontal (equal) or vertical (higher), so that it can identify whether there are ambiguous, inconsistent, or incomplete provisions.

To review or evaluate regulations, the author applied an instrument called the Regulatory Simplification Instrument (Sadiawati et al., 2015:37, 40-41). The analysis steps refer to the IRAC method (issue, rule or relevant law, application or analysis, and conclusion) (Burton, 2016:7). The examining begins with identifying issues regarding the state land and licensing service; investigating the relevant law that governs the issues (national and regional); analyzing the relationship among regulations, including the implication of the new policies or regulations regarding both issues; and conclusion. Based on this method, three alternative 
recommendations could be proposed: the maintained regulation, the revised regulation, or the revoked regulation.

\section{RESULT AND DISCUSSION}

This section describes two things. First, a review of the substance of the four regional regulations governing IMTN. Second, it analyzes the relationship between the four regional regulations and higher laws and regulations.

\section{Governing State Land in East Kalimantan}

As mentioned above that in East Kalimantan, four regions have regional regulations on IMTN, Balikpapan (Perda No.1/2014), Kutai Kartanegara (Perda No. 2/2017), Penajam Paser Utara (Perda No. 18/2017), and Samarinda (Perda No. 2/2019). The four regional regulations have the same systematics and substance as described below.

a. Definition

Perda No. 1/2014, Perda No. 18/2017, and Perda No. 2/2019 have the same definition of IMTN, namely as a permit granted by a regent/mayor or appointed official to an individual or a legal entity to open, take advantage of, and use the state land. Meanwhile, Perda No. 2/2017 defines IMTN as a permit given to an Indonesian citizen to open state land. This definition is different from the three previous regulations. The first difference lies in the permit holder. The three previous regulations state that IMTN can be given to individual and legal entities, while in Perda No. 2/2017, only to individuals. Secondly is the activities that can be carried out with IMTN. The previous three Perda states that IMTN holders can carry out three things, namely opening, taking advantage, and using state land. However, Perda No. 2/2017 only states that permit holders can open state land.

b. Principle

Perda No. 1/2014, Perda No. 18/2017, and Perda No. 2/2019 state transparency, participation, accountability, sustainable development, and public interest principles are the basis of the issuance of IMTN. Meanwhile, Perda No. 2/2017, apart from the five principles, also adds three other principles: equality, expediency, and certainty.

c. Purpose

There are two purposes of establishing Perda on IMTN according to Perda No. 1/2014, Perda No. 2/2017, and Perda No. 2/2019, namely to provide guidelines for the implementation of IMTN services and direct and control the opening of state land so that it is following a spatial planning, environmental capacity, and physical capacity of the land itself. While Perda No. 2/2017 mentions eight objectives, such as guaranteeing land administration, preventing and reducing land disputes, also reducing and preventing the issuance of double certificates.

d. Subject and object

Under Perda No. 2/2017, the subject of IMTN is an individual, while the object is agricultural land and building or housing land. The object also includes ex-mining land or ex-land use rights (HGU) land. This provision is different from Perda No. 1/2014, Perda No. 18/2017, and Perda No. 2/2019, which states that the IMTN subjects are individuals and legal entities, while the objects consist of agricultural and non-agricultural land.

e. Procedure

From a procedural aspect, the four Perda have the same provisions. The four regional regulations stipulate that to obtain IMTN, an applicant must submit a written application to the regent or mayor. If the application is declared complete, it will be registered, and the appointed team performs a site visit to ensure the land location. The results will be announced, and if there is no response/objection within 30 days, the IMTN will be issued. 
However, if in the future, it is proven that the requirements are not correct or not valid, the licensor will revoke the IMTN.

f. Refusal

As with the procedure, the four Perda also have a similar arrangement regarding the IMTN application's rejection. Under regulations, the IMTN refusal is conveyed to the applicant within 7-14 days after receiving the application. The reasons for rejection were incompleteness or incorrect requirements.

g. Validity Period and extension

All the Perda provide a similar validity period of IMTN, that is, three years while regulating the extensions in the different forms. If Perda No. 1/2014, Perda No. 18/2017, and Perda No. 2/2019 states that the extension can be done once and valid for three years. However, under Perda No. 2/2017, the extended IMTN is only legitimate for two years.

h. Rights and obligations

The four Perda declare that the permit holder has the right to open or utilize state land. All regional regulations also govern that IMTN is the basis for submitting applications for land title certificates.

i. Transfer of ownership

Perda No. 18/2017 does not contain provisions regarding the transfer of land ownership. However, the three other Perda regulate this issue, which states that IMTN cannot be transferred or used as collateral.

j. Dispute resolution

The four Perda have the same provisions regarding dispute resolution, which is performed through reconciliation based on deliberation to reach consensus. If during IMTN issuance, there is a protest or claim from other parties, the licensor will verify the documents. In the case of the documents used by the claimant are valid, the licensor rejects the IMTN application. If the supporting evidence submitted is not valid, the parties must settle the case within a specific time. If the parties do not reach an agreement, one should file a lawsuit at the district court.

k. Reports and treaties

Provisions regarding reporting and preparation of agreements are regulated in the four Perda. Under regulations, the appointed official must provide a periodic report to the regent or mayor and prepare an agreement on the land's origin.

Apart from the above, Perda No. 2/2017 provides administrative sanctions, provisions of investigation, and criminal. Meanwhile, Perda No. 18/2017 regulates stipulations on fees related to the issuance of IMTN.

\section{Improvement of IMTN Regulation: A Must}

The examination of the IMTN regulations shows that there are provisions that were ambiguous and incomplete. Also, the review found the disharmony norms in the four regional regulations with higher laws and regulations.

\section{IMTN: An Ambiguous Norm}

Article 39 of Law Number 30 of 2014 concerning Government Administration (Law 30/2014) states that the permit is issued before a person or legal entity conducts an activity. Meanwhile, theoretically, a permit is a constitutive decision, namely provisions that give rise to new rights not previously owned by someone that allows a previously prohibited activity (Sulistiowati, 2012:432).

Referring to the term used in all Perda (IMTN), legally, it is a permit, and it means that IMTN is given before someone carries out activities to open state land. However, the fact 
shows it differently. The IMTN only reaffirms that the land control by a person or legal entity because it was occupied before the issuance of IMTN. Besides, de facto, IMTN is more than an instrument to declare the existing rights, and IMTN is a declarative decision, not a constitutive decision.

The obscure status of IMTN (constitutive or declarative) has implications for the following provisions in such regional regulations. The four Perda on IMTN regulates the procedure in issuing the permit (administrative law) and disputes over property rights that have entered the private law domain. The combination of administrative aspects (licensing procedures and requirements) and the legality of property rights (land rights disputes and its settlement) have obscured the substance of IMTN as a license. Supposedly, as a licensing framework, Perda on IMTN only regulates the administrative aspects of licensing and does not regulate private law issues.

Making IMTN, the basis for submitting land rights certificates also does not have a strong theoretical basis. Conceptually, the land consists of two main aspects. First, the aspects of control and ownership. This aspect relates to how the legal relationship between humans and land. Second, the aspect of use and utilization, which discusses how land is used and utilized (Syahyuti, 2016:14). Referring to this concept, IMTN should be a tool of land and utilization, also as an instrument that regulates the relationship between the permit holder and land (opening, utilizing, or using). To put IMTN as a basis for filing land rights means that it is to make an instrument for land ownership. In the context of land law, the authority to grant land rights is under the National Land Agency (Badan Pertanahan Nasional/BPN) or land office (Kantor Pertanahan) at the regional level, not the district/city government's authority.

Another obscurity is the definition of IMTN itself. Under Perda No. 1/2014, Perda No. 18/2017, and Perda No. 2/2019, IMTN related to activities to open, utilize, or use state land, while in Perda No. 2/2017, IMTN only includes activities to open state land. Does it then raise questions about what activity could be named as opening state land? Does it mean land clearing or land levelling, or a combination of the two? Likewise, the term utilizing or using the state land. What are the differences between the two terms? How can an activity be categorized as utilizing state land? Also, when will it refer to using state land? All the Perda do not explain the meaning of all the terms significantly.

\section{Incompleteness of Provisions}

Investigation of the four Perda on IMTN shows that two norms are not contained in the regional regulations. First, the administrative effort is a provision that regulates the parties' action when the issuance of the IMTN generates a disadvantage for them. The administrative efforts consist of objections and appeals. The party who refuses a government's decision could apply for objection to the agency/official that issued the decree. In this case, the party does not accept the resolution of the objection process, and then the party could propose an appeal to the superior official (appeals stage). It is supposed the party also refuses the appeal's settlement by the superior official. In that case, the party can file a lawsuit at the administrative court.

The four Perda on IMTN only regulate the objection during the issuance process of IMTN, but not after the IMTN was released. Besides, the objections process regulated in the Perda tends to private law aspect because it relates to land ownership disputes, not administration.

The administrative effort provisions are necessary because it becomes a means for applicants if the district/city government rejects their IMTN application. It can also become a legal instrument to withdraw an IMTN for other parties who are disadvantaged by the issuance of the IMTN. Furthermore, Law No. 30/2014 requires administrative efforts before filing a lawsuit with the administrative court. 
The second is the norm regarding complaint management. The four regional regulations only regulate complaints related to land claims of IMTN applicants, which is stipulated in the provisions regarding the procedure and dispute resolution. The existing regional regulations do not yet manage the handling of complaints or public protests regarding IMTN services. Moreover, the Ombudsman Representative Office for East Kalimantan Province has conducted a study on the implementation of IMTN in Balikpapan and found the potential for good administration due to regulations, service procedures, and supervision (Tim Kajian Kebijakan Publik ORI Kalimantan Timur, 2019:31-36).

The complaint management needs to be regulated to ensure suggestions, criticisms, and opinions of the community regarding IMTN services are well managed. Article 8 paragraph (2) of Law Number 25 of 2009 concerning Public Services (Law No. 25/2009) is explained that the implementation of public services includes, among others, the management of public complaints. Article 42 of Government Regulation No. 96 of 2012 concerning Implementation of Law No. 25/2009 state that complaints or reports are part of community involvement in the delivery of public services, and therefore organizers are obliged to provide information to the public regarding the follow-up on the resolution of such inputs, responses, reports, or complaints.

\section{Disharmony with Higher Regulations}

As mentioned above, Law No. 11/2020 introduces a new approach in controlling business activity from a licensing approach to a risk-based approach. Based on the hazard level assessment and the potential hazard assessment, the risk level and business scale rating of business activities are determined into three categories. First, low-risk business activities. Business licensing for activities in this category is a business identification number (NIB). Second, medium-risk business activities in which for this category is issued NIB and standard certificate, this certificate is a statement of business actors to meet business standards in conducting business activities. Third, high-risk business activities, business licensing for business activities at this scale is in the form of granting NIB and permits, which are the Central Government's or Regional Government's approval.

Concerning the three licensing categories, what needs to be underlined is the provision in Law No. 11/2020, which states that the division of concurrent government affairs between the Central and Provincial Governments and district/city as listed in Appendix to Law No. 23/2014 must be read and interpreted following the provisions stipulated in Law No. 11/2020. Consequently, the term permit in IMTN must also be read and interpreted within the business license framework as stated in Law No. 11/2020.

From such a point of view, the existence of the IMTN raises questions. If an action to open state land is classified into low-risk business activity, then it only needs NIB, not a permit. However, when it is categorized into medium-risk business activity, it needs NIB and a standard certificate, not a permit. Further, it is unlikely that the land opening activity could be grouped into high-risk business activity since this category needs high standards and requirements.

As an alternative, the author proposes the term "approval" to replace "permit." The use of this nomenclature refers to the elimination of building permits (Izin Mendirikan Bangunan/IMB) by Law No. 11/2020 and replacing them with building approval. Such approval is given to build new, change, expand, reduce, or maintain buildings following the technical standards (Article 1 point 11 of Law No. 11/2020). Changes in the license's nomenclature to approval can also be seen from the amendment to Article 37 of Law No. 26 of 2007 on Spatial Planning. Then, Law No. 11/2020 changes the term "permit" related to space utilization, from space utilization permits to approval for space utilization. 
Furthermore, Law No. 11/2020 also regulates harmonization. Then, Article No.181 declares that since the enactment of the law, every statutory regulation's provisions that contradict with Law No. 11/2020 or contradicts higher laws and regulations or against court decisions must be harmonized and synchronized under the coordination of the ministry or agency that administers government affairs in the sector of forming laws and regulations. In the context of Perda on IMTN, such harmonization and synchronization need to be done. The Perda on IMTN must adopt provisions on administrative efforts and complaint management, as previously explained. Besides, the Perda on IMTN also needs to adjust the nomenclature, from license to approval.

\section{Proposed Amendment}

Referring to the explanation above, the author argues that the four Perda on IMTN in East Kalimantan should be revised. The alteration, at least, covers the following five aspects:

a. Status and definition of IMTN

The promulgation of Law No. 11/2020 requires an alteration of permit in the activity to open state land to approval (Persetujuan Membuka Tanah Negara/PMTN). Thus, its status will be a declarative decision. Also, there are three activities in opening state land, namely opening, utilizing, and using. These three terms must be clearly defined so that in further regulation, it can be distinguished when an activity is categorized as opening, utilizing, and using state land.

b. Object

The scope of land that can be applied by PMTN should be specific; namely, land with no physical data and juridical data need to follow statutory regulations. Land that already has those documents can directly apply for a land rights certificate to the Land Office. Besides, PMTN objects are executed from land registration objects carried out by the government (BPN/Kantor Pertanahan), such as Complete Systematic Land Registration (Pendaftaran Tanah Sistematis Lengkap/PTSL).

c. Procedure

One of the consequences of changing nomenclature (from license to approval) and simplifying objects is by making application procedures shorter. The primary reference is the suitability of activities to open state land with spatial planning with the detailed spatial plan (Rencana Detail Tata Ruang/RDTR) as mandated by Law No. 11 of 2020. In the application process, it is not required to examine the validity of land ownership, including how to solve the disputes between parties that tend to take time. By making the procedure more straightforward, implementing agencies can provide a transparent and accountable SOP. Trimming the procedures is also intended to avoid similar activities when applying for (previously) IMTN and land title certificates, such as mapping and announcements.

d. Administrative Efforts

It consists of two stages: objection and appeal. Accommodating this issue is intended to provide space for people who feel disadvantaged by the issuance or rejection of PMTN applications.

e. Complaint Management

Arranging the complaint management aims to ensure suggestions, criticisms, and public opinions regarding PMTN services are well managed. It also provides information to the public regarding the follow-up to their input, responses, reports, and complaints submitted.

f. Monitoring and evaluation 
Norms regarding monitoring and evaluation are mandatory because it should be ascertained whether PMTN services are carried out following the statutory regulations or not. The provisions regarding this matter regulate, at least, two aspects: who is doing it and how is the implementation mechanism.

\section{E. CONCLUSION}

In the context of licensing law regimes, IMTN norms' status is unclear, whether as constitutive or declarative decrees. De jure is a constitutive decision because it uses the term permit. It means that IMTN should be given before a person or legal entity begins their activities to open state land. As a permit, the IMTN should stand as an instrument regulating how to use or utilize the land. On the other side, de facto, IMTN means a declarative decision because it only reaffirms existing land tenure. Also, in its implementation, IMTN being a basis for submitting a land rights certificate. It puts IMTN as an instrument governing control or ownership of the land. From the authority aspect, placing the IMTN in such a function is beyond the regional government's authority; it is a jurisdiction of the National Land Agency/Land Office.

As for its relation to higher regulations, Perda on IMTN has not accommodated some provisions on administrative efforts as stipulated in Law no. 30/2014, complaint management as mandated by Law No. 25/2010, and the risk-based approach in business licensing as introduced by Law No. 11/2020. Related to this law, the Perda on IMTN must adjust the nomenclature used from permit to approval because the term permit in Law No. 11/2020 refers to high-risk business activities.

In response to such findings, the Perda on IMTN should be amended to improve the substance and to adjust to higher regulations' norms. The stipulations that should be in the revision include, among others: status and definition of IMTN; object; simplification of application procedures; administrative efforts; complaints management; and monitoring and evaluation. The author proposes two alternatives: first, revoking Perda on IMTN and replacing it with a new one. This suggestion refers to Law No. 12 of 2011 on The Establishment of Laws and Regulations. It states that when the amendment of regulation changes the systematics and content more than 50 percent, such as regulation should be revoked and rearranged in a new one. The second alternative is the revocation and replacing of Perda on IMTN carried out through a Perda on the Implementation of Business Licensing in districts/cities. This alternative is based on Law No. 11/2020. The law orders the regional government to prepare regulations following regional authorities to implement sector business licensing to administer business licensing.

\section{REFERENCES}

Afif Khalid. (2014). Penafsiran Hukum Oleh Hakim Dalam Sistem Peradilan Di Indonesia. Jurnal Al Adl, Volume VI(11), 9-36. https://media.neliti.com/media/publications/225122-penafsiran-hukum-oleh-hakimdalam-sistem-f0c52582.pdf

Anindarini, G., Aditantyo, A., Eryan, A., \& Mutmainah, M. (2020). Beberapa kritik hukum (Seri Analisis, Issue 4). https://icel.or.id/wp-content/uploads/Seri-Analisis-ICELMinerba.rev1_-1.pdf

Asshiddiqie, J. (2000). Tata Urut Perundang-undangan dan Problematika Peraturan Daerah. In Lokakarya Anggota DPRD se-Indonesia.

Asshiddiqie, J., \& Safaat, A. (2006). Teori Hans Kelsen Tentang Hukum (I). Setjen \& Kepaniteraan MK RI.

Asyiah, N. (2017). Strategi Implementasi Perizinan Dan Sanksi Administratif Sebagai 
Pembatasan Terhadap Kebebasan Bertindak. Jurnal Hukum Samudra Keadilan, 12(1), 123-135. https://media.neliti.com/media/publications/240387-strategi-implementasiperizinan-dan-sank-94333c35.pdf

Bachriadi, D., \& Wiradi, G. (2011). Enam Dekade Ketimpangan: Masalah Penguasaan Tanah di Indonesia. Agrarian Resource Centre, Bina Desa \& KPA. https://arc.or.id/wpcontent/uploads/2014/11/edk.pdf

Batten, D. (2010). Ambiguity. In Gale Encyclopedia of American Law: Vols. 1: A-BA (3rd ed.). Gale Cengage Learning.

Bezborodov, Y. (2017). Methods of International Legal Convergence. Law Review, VII(1), 21-31. https://doi.org/10.4324/9781315005355-21

Budiman, A. (2020). Pensertifikatan Tanah Negara Oleh Masyarakat Menjadi Hak Milik. Jurnal Hukum Dan Kenotaratan, 4(2), 158-172. http://riset.unisma.ac.id/index.php/hukeno/article/view/8635/pdf

Burton, K. (2016). Teaching and assessing problem-solving: An example of an incremental approach to using irac in legal education. Journal of University Teaching and Learning Practice, 13(5). https://files.eric.ed.gov/fulltext/EJ1124439.pdf

Dear, D. (2017). Kedudukan Hukum IMTN dalam Pendaftaran Tanah [Universitas Brawijaya]. In repository.ub.ac.id. http://repository.ub.ac.id/9456/1/Dianne Dear.pdf

Garner, B. A. (2009). Black'S Law Dictionary (Bryan A. Garner (ed.); 9th ed.). West Thompson Reuters.

Goesniadhie, K. (2006). Harmonisasi hukum dalam perspektif perundang-undangan: lex spesialis suatu masalah (1st ed.). JP Books.

Hadi, S., \& Michael, T. (2017). Principles of Defense (Rechtmatigheid) In Decision Standing of State Administration. Jurnal Cita Hukum, 5(2), 383-400. https://doi.org/10.15408/jch.v5i2.7096

Herman, H. (2015). Perlindungan Hukum Warga Negara Terhadap Tindakan Pemerintah Dalam Membuat Keputusan Administrasi Negara. Jurnal Komunikasi Hukum (JKH), 1(1), 43-54. https://doi.org/10.23887/jkh.v1i1.5012

Hesselink, M. W. (2009). A European Legal Science? On European private law and scientific method. European Law Journal, 15(1), 20-45. https://papers.ssrn.com/sol3/papers.cfm?abstract_id=1113450

Hutchinson, T. (2016). The Doctrinal Method: Incorporating Interdisciplinary Methods in Reforming the Law. Erasmus Law Review, 38(3), 130-138. https://doi.org/10.5553/elr.000055

Ichsan, M., Prasetyoningsih, N., \& Satriawan, I. (2020). Pemberlakuan Syariat Islam dalam Peraturan Daerah Di Indonesia (I). Laboratorium Fakultas Hukum Universitas Muhammadiyah Yogyakarta.

Jade, A. P., Putri, D. N., \& Al-Fatih, S. (2020). Perizinan Membuka Tanah Negara Di Kota Balikpapan. Supremasi Hukum: Jurnal Penelitian Hukum, 29(2), 102-130. https://ejournal.unib.ac.id/index.php/supremasihukum/article/view/12254/6608

Katharina Pistor and Chenggang Xu. (2003). Incomplete Law. International Law and Politics, 35(931), 931-1014.

Kharel, A. (2018). Doctrinal Legal Research. SSRN Electronic Journal. https://doi.org/10.2139/ssrn.3130525

Lofus, R. F. (2019). Hak dan Kewajiban Pejabat Pemerintahan Menurut Undang-Undang Nomor 30 Tahun 2014 Tentang Administrasi Pemerintahan. Jurnal Lex Administratum, VII(1), 5-16. https://jurnal.ugm.ac.id/jmh/article/view/16113/10659

Luhfitasari, R., Azzahra, S. Z., Angraeni, A. D., \& Kasih, A. M. (2020). Perlindungan Hukum Bagi Pemegang IMTN Berdasarkan Perda Kota Balikpapan No. 1 Tahun 2014 tentang Izin Membuka Tanah Negara. Jurnal de Jure, 12(1), 21-27. 
http://download.garuda.ristekdikti.go.id/article.php?article=1648721\&val=15052\&title= PERLINDUNGAN HUKUM BAGI PEMEGANG IMTN BERDASARKAN PERATURAN DAERAH KOTA BALIKPAPAN NO 1 TAHUN 2014 TENTANG IZIN MENDIRIKAN TANAH NEGARA

McLeod, I. (1999). Kelsen's Hierarchy of Norms. In Legal Theory (pp. 68-83). Macmillan Law Masters. https://doi.org/10.1007/978-1-349-14269-9_5

Otto, J. M., Stoter, W. S. R., \& J. Arnscheidt. (2008). Using legislative theory to improve law and development projects. In B. van Rooij, J. Arnscheidt, \& J.M. Otto (Eds.), Lawmaking for development: An introduction (pp. 53-74). Leiden University Press.

Permatasari, I. A., Suhariningsih, \& Sucipto. (2015). Perlindungan Hukum Bagi Pemegang Hak Atas Tanah Berdasarkan Alat Bukti Segel Tanah (Dalam Rangka Penerapan Peraturan Daerah Kota Balikpapan No. 1 tahun 2014 tentang Izin Membuka Tanah negara. Http://Hukum.Studentjournal.Ub.Ac.Id. http://hukum.studentjournal.ub.ac.id/index.php/hukum/article/view/1232

Riyanto, S., Sumardjono, M. S. ., Hiriej, E. O. ., Sulistiowati, Hernawan, A., Mochtar, Z. A., Diantoro, T. D., Yuniza, M. E., Wardana, I. G. A. M., \& Izzati, N. R. (2020). Kertas Kebijakan: Catatan Kritis dan Rekomendasi Terhadap RUU Cipta Kerja. In Fakultas Hukum Universitas Gadjah Mada.

Rukmana, I., \& Darmini, N. (2015). Tinjauan Yuridis Perjanjian Pengikatan Jual Belidalam Proses Penyerahan Hak Penguasaan Tanah Atas Dasar Surat Izin Membuka Tanah Negara Dikota Balikpapan [Universitas Gadjah Mada, Yogyakarta]. http://etd.repository.ugm.ac.id/home/detail_pencarian/91605

Sadiawati, D., Lilly Widayati, N, M. S., \& Malaysianto, P. (2015). Strategi Nasional Reformasi Regulasi. Bappenas. https://www.bappenas.go.id/id/publikasi-informasiaplikasi-dan-tautan/publikasi/strategi-nasional-reformasi-regulasi/

Sari, D. R. (2017). Surat Izin Membuka Tanah Negara Berdasarkan Peraturan Daerah Kota Balikpapan Nomor 1 Tahun 2014 Kaitannya Dengan Peraturan Pemerintah Nomor 24 Tahun 1997 Tentang Pendaftaran Tanah. Universitas Hasanuddin.

Sauni, H. (2017). Konflik Penguasaan Tanah Perkebunan. University Of Bengkulu Law Journal, 1(1), 45-67. https://doi.org/10.33369/ubelaj.v1i1.1327

Shidarta. (2005). Kerangka Berpikir Harmonisasi Peraturan Perundang-undangan dalam Pengelolaan Pesisir. In J. M. Patlis, T. H. Purwaka, A. Wiyana, \& G. H. Perdanahardja (Eds.), Menuju Harmonisasi Sistem Hukum Sebagai Pilar Pengelolaan Wilayah Pesisir Indonesia. Kementerian Perencanaan Pembangunan Nasional, Departemen Kelautan dan Perikanan, Departemen Hukum dan HAMbekerja sama dengan Coastal Resources Management Project II (USAID).

Shohibuddin, M. (2019). Memahami Dan Menanggulangi Persoalan Ketimpangan Agraria (2). BHUMI: Jurnal Agraria Dan Pertanahan, 5(2), 136-149. https://doi.org/10.31292/jb.v5i2.366

Soegiyono. (2015). Pentingnya Harmonisasi dalam Pembentukan Peraturan PerundangUndangan. Kajian Kebijakan Dan Hukum Kedirgantaraan, 1-21. https://doi.org/10.30536/9786023181339.1

Sugiharto, H., \& Abrianto, B. O. (2018). Perlindungan Hukum Non Yudisial Terhadap Perbuatan Hukum Publik Oleh Pemerintah. Yuridika, 33(1), 41-72. https://doi.org/10.20473/ydk.v33i1.7280

Sulistiowati, M. (2012). Penerapan Prinsip Lisensi dalam Pemberian Izin Penyelenggaraan Layanan Publik. Mimbar Hukum - Fakultas Hukum Universitas Gadjah Mada, 24(3), 431-442. https://doi.org/10.20303/jmh.v24i3.403

Sumardjono, M. S. (2018). Regulasi Pertanahan dan Semangat Keadilan Agraria. STPN 
Press.

Supriyanto. (2008). Implementasi Kebijakan Pertanahan Nasional. Jurnal Dinamika Hukum, 8(3), 221-231. https://doi.org/10.20884/1.jdh.2008.8.3.78

Sutedi, A. (2011). Hukum Perizinan Dalam Sektor Pelayanan Publik (Tarmizi (ed.); 1st ed.). Sinar Grafika.

Suyani, E. (2016). Epistemologi Keputusan Administrasi Yang Berkeadilan Dalam Mewujudkan Good Governance. Jurnal Publik, I(June), 12-30. http://jurnal.dharmawangsa.ac.id/index.php/jupublik/article/view/293/287

Syahyuti, N. (2016). Nilai-Nilai Kearifan pada Konsep Penguasaan Tanah Menurut Hukum Adat di Indonesia. Forum Penelitian Agro Ekonomi, 24(1), 14-27. https://doi.org/10.21082/fae.v24n1.2006.14-27

Tim Kajian Kebijakan Publik ORI Kalimantan Timur. (2019). Potensi Maladministrasi dalam Penyelenggaraan Layanan Izin Membuka Tanah Negara di Kota Balikpapan.

Waddell, S. K. (2004). The Role of The "Legal Rule" In Indonesian Law: environmental law and reformasi of water quality management [University of Sidney]. In Environmental Management. $\quad$ https://ses.library.usyd.edu.au/bitstream/handle/2123/673/adtNU20050120.16081702whole.pdf?sequence=1\&isAllowed=y 